\title{
A prospective clinical study of feto-maternal outcome in pregnancies with abnormal liquor volume
}

\author{
Rutwa J. Chavda, Hardev B. Saini*
}

\begin{abstract}
Department of Obstetrics \& Gynecology, SBKS MIRC and Dhiraj General Hospital, Pipariya, Waghodia, Vadodara,
\end{abstract} Gujarat, India

Received: 1 February 2014

Accepted: 16 February 2014

*Correspondence:

Dr. Hardev B. Saini,

E-mail: drsainihb@yahoo.co.in

(C) 2014 Chavda RJ et al. This is an open-access article distributed under the terms of the Creative Commons Attribution Non-Commercial License, which permits unrestricted non-commercial use, distribution, and reproduction in any medium, provided the original work is properly cited.

\section{ABSTRACT}

Background: Evaluating feto-maternal outcome in pregnancies with abnormal liquor volume.

Methods: 200 pregnant subjects between 20 and 42 weeks of gestation, who were clinically suspected to have an abnormal amniotic fluid volume (oligohydramnios or polyhydramnios) were subjected to ultrasonographic (USG) assessment of amniotic fluid index. The subjects were closely monitored during pregnancy, labour and puerperium.

Results: Ultrasonically, abnormal liquor volume was confirmed in 90-93\% clinically suspected patients. Post term pregnancy $(39 \%)$, PROM $(30 \%)$ and prolonged pregnancy $(24 \%)$ were associated with oligohydramnios. Fetal congenital anomalies (31\%), diabetes mellitus (20\%), PIH (18\%), twin pregnancy (7\%) and Rh incompatibility (4\%) were associated with polyhydramnios. The incidence of labour induction, fetal labour intolerance, CS for fetal distress and 1 min APGAR of $<7$ was high in oligohydramnios -subjects. Premature labour complicated $40 \%$ of polyhydramnios pregnancies. The overall incidence of congenital anomalies (14\%) and perinatal mortality $(20 \%)$ in subjects with abnormal liquor volume was significantly higher $(\mathrm{P}<0.001)$ than in women with normal liquor volume $(0.3,2.3 \%$ respectively).

Conclusions: A good clinical examination can pick up most subjects of abnormal liquor volume. Abnormal liquor volumes are associated with increased maternal morbidity and adverse perinatal outcome.

Keywords: Oligohydramnios, Polyhydramnios, Congenital anomalies, Premature rupture of membranes (PROM), Stillbirth

\section{INTRODUCTION}

Amniotic fluid provides temperature stability, cushioning and a necessary presence in collapsed airways to help stimulate lung development. The importance of amniotic fluid volume as an indicator of fetal wellbeing has made its assessment an important part of antenatal fetal surveillance. Abnormalities such as meconium staining, congenital anomalies, growth retardation, dysmaturity and fetal asphyxia have been associated with reduced amniotic fluid volume. ${ }^{1}$ Polyhydramnios is sometimes associated with major fetal anomalies, ${ }^{2}$ aneuploidy, macrosomia and stillbirth. ${ }^{3}$ It has been proposed that amniotic fluid possesses certain bacteriostatic properties that protect against potential infectious processes and that a decrease in amniotic fluid volume may impair the gravid woman's' ability to combat such infections. ${ }^{4}$

We report a clinical study of fetomaternal outcome in pregnancies with abnormal liquor volume managed at a tertiary care hospital.

\section{METHODS}

This prospective study was carried out in the Department of Obstetrics and Gynaecology, at Dhiraj General Hospital, Pipariya, Gujarat between 1.6.2012 and 31.5.2013. A total of 7,108 antenatal subjects attended the OPD during this period. On the basis of a thorough clinical examination performed between 20 and 42 
weeks, $247(3.4 \%)$ subjects were suspected to have an abnormal amniotic fluid volume. Of these, 200 women who attended the ANC OPD regularly and were closely monitored during pregnancy, labour and puerperium, made up the study population.

Detailed data was recorded and investigations carried out. They were subjected to ultrasound examination and assessment of amniotic fluid index, every 2 weeks between 20 and 35 weeks, every week between 36 and 40 weeks and twice weekly thereafter. The data obtained was tabulated and analysed using SPSS 11.5. Appropriate statistical analysis using t test, v2 test was applied.

\section{RESULTS}

Of the 200 subjects, 150 were clinically suspected to have low AFI, while 140 (93\%) were ultrasonographically confirmed to have low AFI $(<5)$. $71 \%$ of oligohydramnios subjects belonged to the 21-30 years age group (Table 1) and $41 \%$ were nulliparous (Table 2 ).

Table 1: Distribution of subjects by age.

\begin{tabular}{|c|c|c|c|c|c|}
\hline \multirow[t]{2}{*}{$\begin{array}{l}\text { Age } \\
\text { (years) }\end{array}$} & \multicolumn{2}{|c|}{$\begin{array}{l}\text { Oligohydramnios } \\
(n=40)\end{array}$} & \multicolumn{3}{|c|}{ Polyhydramnios $(\mathrm{n}=45)$} \\
\hline & $<5 \mathrm{~cm}$ & $\begin{array}{l}5.1-8 \\
\mathrm{~cm}\end{array}$ & $\begin{array}{l}25-30 \\
\mathrm{~cm}\end{array}$ & $\begin{array}{l}\text { 30.1-35 } \\
\text { cm }\end{array}$ & $\begin{array}{l}<35 \\
\mathrm{~cm}\end{array}$ \\
\hline $15-20$ & $\begin{array}{l}6 \\
(4 \%)\end{array}$ & $\begin{array}{l}10 \\
(7.1 \%)\end{array}$ & $\begin{array}{l}2 \\
(4.2 \%)\end{array}$ & $\begin{array}{l}3 \\
(6 \%)\end{array}$ & - \\
\hline $21-25$ & $\begin{array}{l}16 \\
(11.4 \%)\end{array}$ & $\begin{array}{l}55 \\
(39.2 \%)\end{array}$ & $\begin{array}{l}7 \\
(14 \%)\end{array}$ & $\begin{array}{l}8 \\
(16 \%)\end{array}$ & - \\
\hline $26-30$ & $\begin{array}{l}8 \\
(5.7 \%)\end{array}$ & $\begin{array}{l}20 \\
(14.2 \%)\end{array}$ & $\begin{array}{l}11 \\
(24.4 \%)\end{array}$ & $\begin{array}{l}6 \\
(13.3 \%)\end{array}$ & $\begin{array}{l}2 \\
(4.4 \%)\end{array}$ \\
\hline$<30$ & $\begin{array}{l}10 \\
(7.1 \%)\end{array}$ & $\begin{array}{l}15 \\
(10.7 \%)\end{array}$ & $\begin{array}{l}5 \\
(10 \%)\end{array}$ & - & $\begin{array}{l}1 \\
(2.2 \%)\end{array}$ \\
\hline
\end{tabular}

$\mathrm{P}<0.05$

Table 2: Distribution of subjects by parity.

\begin{tabular}{|c|c|c|c|c|c|}
\hline \multirow[t]{2}{*}{ Parity } & \multicolumn{2}{|c|}{$\begin{array}{l}\text { Oligohydramnios } \\
(n=140)\end{array}$} & \multicolumn{3}{|c|}{ Polyhydramnios $(\mathrm{n}=45)$} \\
\hline & $<5 \mathrm{~cm}$ & $\begin{array}{l}5.1-8 \\
\mathrm{~cm}\end{array}$ & $\begin{array}{l}25-30 \\
\mathrm{~cm}\end{array}$ & $\begin{array}{l}\text { 30.1-35 } \\
\mathrm{cm}\end{array}$ & $\begin{array}{l}<35 \\
\mathrm{~cm}\end{array}$ \\
\hline $\mathrm{P}_{0}$ & $\begin{array}{l}18 \\
(12.8 \%)\end{array}$ & $\begin{array}{l}40 \\
(28.5 \%)\end{array}$ & $\begin{array}{l}4 \\
(8.8 \%)\end{array}$ & $\begin{array}{l}2 \\
(4.4 \%)\end{array}$ & - \\
\hline $\mathrm{P}_{1}$ & $\begin{array}{l}12 \\
(8.5 \%)\end{array}$ & $\begin{array}{l}25 \\
(17.8 \%)\end{array}$ & $\begin{array}{l}6 \\
(13.3 \%)\end{array}$ & $\begin{array}{l}4 \\
(8.8 \%)\end{array}$ & - \\
\hline $\mathrm{P}_{2}$ & $\begin{array}{l}6 \\
(4.4 \%)\end{array}$ & $\begin{array}{l}15 \\
(10.7 \%)\end{array}$ & $\begin{array}{l}4 \\
(8.8 \%)\end{array}$ & $\begin{array}{l}3 \\
(6.6 \%)\end{array}$ & $\begin{array}{l}1 \\
(2.2 \%)\end{array}$ \\
\hline $\mathrm{P}_{3}$ & $\begin{array}{l}4 \\
(2.8 \%)\end{array}$ & $\begin{array}{l}20 \\
(14.2 \%)\end{array}$ & $\begin{array}{l}6 \\
(13.3 \%)\end{array}$ & $\begin{array}{l}8 \\
(17.7 \%)\end{array}$ & $\begin{array}{l}2 \\
(4.4 \%)\end{array}$ \\
\hline $\mathrm{P}_{4}$ & - & - & $\begin{array}{l}5 \\
(11.1 \%)\end{array}$ & - & - \\
\hline Total & 40 & & & & \\
\hline
\end{tabular}

$\mathrm{P}<0.0001$
$39 \%$ had post term pregnancy, 30\% had premature rupture of membranes (PROM) and 24\% had prolonged pregnancy (Table 3).

Table 3: Factors associated with oligohydramnios.

\begin{tabular}{|llll|}
\hline Factors & AFI (cm) & Total No. \\
\hline \multirow{2}{*}{ PIH } & 5 & 23 & 27 \\
& $(3.5 \%)$ & $(16.4 \%)$ & \\
\hline \multirow{2}{*}{ PROM } & $\begin{array}{l}10 \\
(7.1 \%)\end{array}$ & $\begin{array}{l}32 \\
(2.8 \%)\end{array}$ & $\begin{array}{l}42 \\
(30 \%)\end{array}$ \\
\hline \multirow{2}{*}{ Malpresentation } & 19 & 20 & 39 \\
& $(13.5 \%)$ & $(14.2 \%)$ & $(27.8 \%)$ \\
\hline Chronic abruption & 0 & $1(0.7 \%)$ & $1(0.7 \%)$ \\
\hline Prolonged pregnancy & 15 & 18 & 33 \\
& $(10.7 \%)$ & $(12.8 \%)$ & $(23.5 \%)$ \\
\hline \multirow{2}{*}{ Post term pregnancy } & 20 & 34 & 54 \\
& $(14.2 \%)$ & $(24.2 \%)$ & $(38.5 \%)$ \\
\hline Fetal congenital & 7 & 5 & 12 \\
anomalies & $(4.2 \%)$ & $(3.5 \%)$ & $(8.5 \%)$ \\
\hline IUGR & 20 & $\begin{array}{l}16 \\
(14.2 \%)\end{array}$ & 36 \\
& $(11.4 \%)$ & $(25.7 \%)$ \\
\hline
\end{tabular}

Table 4: Factors associated with polyhydramnios.

\begin{tabular}{|c|c|c|c|c|}
\hline \multirow[t]{2}{*}{ Factors } & \multicolumn{3}{|c|}{ AFI (cm) } & \multirow[t]{2}{*}{$\begin{array}{l}\text { Total } \\
\text { No. }\end{array}$} \\
\hline & $\begin{array}{l}25-30 \\
\text { cm }\end{array}$ & $\begin{array}{l}30-35 \\
\text { cm }\end{array}$ & $\begin{array}{l}>35 \\
\text { cm }\end{array}$ & \\
\hline $\begin{array}{l}\text { Diabetes } \\
\text { mellitus }\end{array}$ & $\begin{array}{l}5 \\
(11.1 \%)\end{array}$ & $\begin{array}{l}4 \\
(8.8 \%)\end{array}$ & - & $\begin{array}{l}9 \\
(20 \%)\end{array}$ \\
\hline $\mathrm{PIH}$ & $\begin{array}{l}4 \\
(8.8 \%)\end{array}$ & $\begin{array}{l}2 \\
(4.4 \%)\end{array}$ & $\begin{array}{l}2 \\
(4.4 \%)\end{array}$ & $\begin{array}{l}8 \\
(17.7 \%)\end{array}$ \\
\hline PROM & $\begin{array}{l}10 \\
(22.2 \%)\end{array}$ & $\begin{array}{l}9 \\
(20 \%)\end{array}$ & $\begin{array}{l}1 \\
(2.2 \%)\end{array}$ & $\begin{array}{l}20 \\
(44.5 \%)\end{array}$ \\
\hline Preterm labour & $\begin{array}{l}10 \\
(22.2 \%)\end{array}$ & $\begin{array}{l}6 \\
(13.3 \%)\end{array}$ & $\begin{array}{l}2 \\
(4.4 \%)\end{array}$ & $\begin{array}{l}18 \\
(40 \%)\end{array}$ \\
\hline Malpresentation & $\begin{array}{l}1 \\
(2.2 \%)\end{array}$ & $\begin{array}{l}2 \\
(4.4 \%)\end{array}$ & $\begin{array}{l}3 \\
(6.6 \%)\end{array}$ & $\begin{array}{l}6 \\
(13.3 \%)\end{array}$ \\
\hline $\begin{array}{l}\text { Twin } \\
\text { pregnancy }\end{array}$ & $\begin{array}{l}1 \\
(4.4 \%)\end{array}$ & $\begin{array}{l}1 \\
(2.2 \%)\end{array}$ & - & $\begin{array}{l}3 \\
(6.6 \%)\end{array}$ \\
\hline Cord prolapsed & - & $\begin{array}{l}1 \\
(2.2 \%)\end{array}$ & $\begin{array}{l}1 \\
(2.2 \%)\end{array}$ & $\begin{array}{l}2 \\
(4.4 \%)\end{array}$ \\
\hline $\begin{array}{l}\mathrm{Rh} \\
\text { incompatibility }\end{array}$ & $\begin{array}{l}1 \\
(2.2 \%)\end{array}$ & - & $\begin{array}{l}1 \\
(2.2 \%)\end{array}$ & $\begin{array}{l}2 \\
(4.4 \%)\end{array}$ \\
\hline $\mathrm{PPH}$ & - & - & $\begin{array}{l}2 \\
(4.4 \%)\end{array}$ & $\begin{array}{l}2 \\
(4.4 \%)\end{array}$ \\
\hline $\begin{array}{l}\text { Fetal congenital } \\
\text { anomalies }\end{array}$ & $\begin{array}{l}8 \\
(17.7 \%)\end{array}$ & $\begin{array}{l}4 \\
(8.8 \%)\end{array}$ & $\begin{array}{l}2 \\
(4.4 \%)\end{array}$ & $\begin{array}{l}14 \\
(31.1 \%)\end{array}$ \\
\hline
\end{tabular}

$44 \%$ of the oligohydramnios subjects went into spontaneous labour. Of them, 90\% needed augmentation of labour and $74 \%$ delivered vaginally. $57 \%$ of oligohydramnios subjects were induced and $44 \%$ delivered vaginally (Table 4). Overall, 57\% delivered vaginally. The incidence of meconium staining, abnormal fetal heart rate (FHR) patterns, caesarean section (CS) for 
fetal distress (80\%) and 1 min APGAR of <7 (39\%) was high in oligohydramnios subjects.

Of the 50 clinically suspected subjects of polyhydramnios, 7 were between 20 and 28 weeks and 43 $>28$ weeks. In 13 subjects who had a normal liquor volume at 20 weeks, polyhydramnios developed gradually during the third trimester. Overall $45(90 \%)$ were confirmed by USG. 55\% had moderate elevated AFI $(30.1-35 \mathrm{~cm})$ while $6.8 \%$ had markedly elevated AFI $(>35 \mathrm{~cm}) .6 \%$ of polyhydramnios subjects belonged to 21-30 years age group and $13 \%$ were nulliparous (Tables 1 and 2).

As shown in Table 3 subjects with AFI of $<5 \mathrm{~cm}$ had a higher probability of malpresentation ( $\mathrm{P}<0.0001)$, prolonged pregnancy, post term pregnancy and fetal congenital anomalies $(\mathrm{P}<0.05)$ as compared to subjects with AFI between 5.1 and $8 \mathrm{~cm}$.

Malpresentation and PIH were found to be significantly higher $(\mathrm{P}<0.05)$ with liquor volumes of $>35 \mathrm{~cm}$. While comparing the two groups, it was observed that malpresentation was more common in the oligohydramnios group, whereas fetal congenital anomalies was significantly highly associated with polyhydramnios $(\mathrm{P}<0.05)$

Fetal congenital anomalies were present in $31 \%$, diabetes mellitus in $20 \%$, PIH in $18 \%$, twin pregnancy in $7 \%$ and $\mathrm{Rh}$ incompatibility in $4 \%$. None of the women with diabetes had any congenital anomaly (Table 4).

$87 \%$ of the polyhydramnios subjects went into spontaneous labour, $40 \%$ prematurely. Of these, $39 \%$ needed augmentation of labour and $82 \%$ delivered vaginally. $13 \%$ of the polyhydramnios subjects had to be induced due to co-morbid factors, of whom $50 \%$ delivered vaginally.

Overall $43 \%$ oligohydramnios as against $22 \%$ of polyhydramnios subjects underwent CS $(\mathrm{P}<0.01)$. The average duration of labour in oligohydramnios was significantly longer $(\mathrm{P}<0.001)$ than in polyhydramnios subjects; this indicated that there was no significant difference in terms of fetal weight or sex. The incidence of malpresentation was $13 \%$ in polyhydramnios; cord prolapsed $(11 \%)$ and PPH $(4 \%)$ were dreaded complications. 5

Perinatal mortality in polyhydramnios subjects (42\%) was significantly higher $(\mathrm{P}<0.001)$ than in oligohydramnios subjects $(13 \%)$. The incidence of congenital anomalies was $9 \%$ in the oligohydramnios group; the most common anomaly was of genitourinary system. Amongst polyhydramnios subjects it was $31 \%$, the common anomalies being hydrocephalus, anencephaly, spina bifida and duodenal atresia (Table 5).
Table 5: Distribution of congenital anomalies in oligohydramnios and polyhydramnios.

\begin{tabular}{|lll|}
\hline Congenital anomaly & $\begin{array}{l}\text { Oligohyd- } \\
\text { ramnios }\end{array}$ & $\begin{array}{l}\text { Polyhyd- } \\
\text { ramnios }\end{array}$ \\
\hline Hydrocephalus & - & 5 \\
\hline Anencephaly & - & 3 \\
\hline Meningocele & - & 1 \\
\hline Spina bifida & - & 2 \\
\hline Oesophageal atresia & - & 1 \\
\hline Duodenal atresia & - & 2 \\
\hline Omphalocele & 2 & - \\
\hline B/L polycystic kidney & 3 & - \\
\hline $\begin{array}{l}\text { Hydronephrosis with } \\
\text { hydroureter }\end{array}$ & 2 & - \\
\hline Cleft lip with cleft palate & 3 & - \\
\hline Phocomelia & 1 & - \\
\hline Total & 12 & 14 \\
\hline
\end{tabular}

$\mathrm{P}<0.01$

While congenital anomaly was not the cause of any perinatal death in the oligohydramnios group, it was responsible for $32 \%$ deaths in polyhydramnios group. None of the women with polyhydramnios and diabetes mellitus had any congenital anomaly in the present study. In the absence of diabetes however, polyhydramnios was significantly associated with congenital anomalies. The perinatal mortality was higher in polyhydramnios (42\%) than in oligohydramnios $(13 \%)$ subjects. ${ }^{6,7}$ The overall incidence of congenital anomalies $(14 \%)$ and perinatal mortality (20\%) in subjects with abnormal liquor volume was significantly higher $(\mathrm{P}<0.001)$ than in women with normal liquor volume.

\section{DISCUSSION}

This study was undertaken to assess the value of a thorough obstetric examination in detecting abnormalities of liquor volume. The variation in clinically suspected and USG confirmed oligohydramnios (7\%) and polyhydramnios $(10 \%)$ is fairly acceptable and compares with those reported in the literature 5-6\%., When oligohydramnios is detected in the second or early third trimester, a level 3 USG to detect fetal congenital anomalies is necessary as its incidence may vary from $8 \%$ (present study) to $9-26 \%$ in other studies. ${ }^{8}$ In the absence of any evidence of infection, associated complications and a reassuring biophysical profile $(24 \%$ of our subjects had an adequate amniotic fluid pocket of $>2 \mathrm{~cm}$ as required in biophysical profile), none of our patients were induced. $36 \%$ delivered within 2 weeks while the rest continued with their pregnancies under proper supervision. When oligohydramnios was associated with an additional risk factor, the incidence of induction was high (57\%). The incidence of CS in our study $(43 \%)$ is high as compared to others (10\% in Sarno et al. study). Fetal distress was the commonest indication of CS. Fetal monitoring in labour is by FHR auscultation, 
intermittent cardiotocography and observation of the colour of liquor should be done.

A metaanalysis by Chauhan et al. ${ }^{9}$ included all published studies between 1987 and 1997. Because of the heterogeneity of data or small study population, they could not correlate antepartum AFI with neonatal outcome. However, they could find no correlation between intra- partum AFI $<5$ and neonatal acidosis. Different investigators have suggested different cut off to identify high risk women. Baron et al. ${ }^{10}$ and Rutherford et al. ${ }^{11}$ have suggested $<5 \mathrm{~cm}$ AFI as the cut-off while Moore and Cayle ${ }^{12}$ suggested a cut off of $<8 \mathrm{~cm}$. Magann et al. $^{13}$ in their study of 79 women with AFI $<5$ but excluding those with severe IUGR or congenital anomalies, found no additional risk of adverse fetal outcome.

The criteria used to define polyhydramnios effects its prevalence. Thus, a single pocket of $8 \mathrm{~cm}$ diagnoses more patients $^{7}$ as compared to an AFI of $>25 \mathrm{~cm}^{14}$ Also, the more severe the polyhydramnios, the greater was the likelihood of finding a cause for it. ${ }^{15}$ Preterm labour was seen in $40 \%$ against a reported prevalence of $11-29 \%{ }^{6}$ Neonatal outcome in prematurity is influenced by a number of variables such as poverty, literacy (nonmodifiable in the short term) and availability of quality NICU and effective paediatric surgery unit. Since the latter are available only in tertiary referral hospitals, it is prudent that all women with abnormal liquor volume are referred to a higher centre at the earliest to optimise neonatal outcome. Since the incidence of diabetes mellitus in polyhydramnios was found to be high $20 \%$ (2$7 \%$ in the literature), there is a need to screen these subjects repeatedly during the course of pregnancy and establish early euglycemia.

\section{CONCLUSIONS}

A good clinical examination can usually identify subjects with abnormal liquor volume. An increased or decreased liquor volume, inappropriate for gestational age, is associated with an increased incidence of complications in labour, caesarean section and adverse perinatal outcome. Since facilities for USG, are not available at all primary and community health centres (PHC, CHC), a good clinical examination can pick up all such subjects at primary level who can be referred early to higher centres for proper management.

\section{Funding: No funding sources}

Conflict of interest: None declared

Ethical approval: The study was approved by the institutional ethics committee

\section{REFERENCES}

1. Moore TR. Amniotic fluid dynamics reflect fetal and maternal health and disease. Obstet Gynecol. 2010;116:759-65.
2. Hashimoto BE, Kramer DJ, Brennan L. Amniotic fluid volume: fluid dynamics and measurement technique. Semin Ultrasound CT MR. 1993;14:4055.

3. Sarno Albert P, Ahn Myoung O, Phelan Jeffrey P. Intrapartum amniotic fluid volume at term. J Reprod Med. 1990;35:719-23.

4. Vermillion Stephen T, Kooba Austin M, Soper David E. Amni - otic fluid index values after preterm premature rupture of the membranes and subsequent perinatal infection. Am $\mathrm{J}$ Obstet Gynecol. 2000; 183:271-5.

5. Newbould MJ, Lendon M, Barson AJ. Oligohydramnios sequence; the spectrum of renal malformations. Br J Obstet Gynaecol. 1994;101:598604.

6. Ariel M, Hill Lyndon M, Lazebnic Noam, et al. The association between polyhydramnios and preterm delivery. Obstet Gynecol. 1995;86:389-91.

7. Carlson DE, Platt Lawrence D, Medearis Arnold L, et al. Quantifiable polyhydramnios: diagnosis and management. Obstet Gynecol. 1990;75:989-92.

8. Panting-Kemp Andrea, Nguyen Tuan, Chang Elaine, et al. Idiopathic polyhydramnios and perinatal outcome. Am J Obstet Gynecol. 1999;181:1079-82.

9. Chauhan SP, Sharp TW, Runjel AR, et al. Intrapartum amniotic fluid index and adverse outcome: experience at a community hospital. J Matern Fetal Invest. 1993;3:37-9.

10. Baron BC, Morgan MA, Garite TJ. The impact of amniotic fluid volume assessed intrapartum on perinatal outcome. Am J Obstet Gynecol. 1995;173:167-74.

11. Rutherford SE, Phelan JP, Smith CV, et al. The four quadrant assessment of amniotic fluid volume: an adjunct to antenatal fetal heart rate testing. Obstet Gynecol. 1987;70:353-6.

12. Moore Thomas R, Cayle Jonathan E. The amniotic fluid index in normal human pregnancy. Am J Obstet Gynecol. 1990;162:1168-73.

13. Magann EF, Doherty DA, Lutgendorf MA, et al. Peripartum outcomes of high-risk pregnancies complicated by oligo - and polyhydramnios: a prospective longitudinal study. J Obstet Gynecol. 2010;36:268-77.

14. Brady K, Polzin WJ, Kopelman JN, et al. Risk of chromosomal abnormalities in patients with idiopathic polyhydramnios. Obstet Gynecol. 1992;79:234-8.

15. Hill LM, Breckle R, Thomas ML, et al. Polyhydramnios: ultrasonically detected prevalence and neonatal outcome. Obstet Gynecol. 1987;69:215 .

DOI: $10.5455 / 2320-1770 . i j \operatorname{cog} 20140336$

Cite this article as: Chavda RJ, Saini HB. A prospective clinical study of feto-maternal outcome in pregnancies with abnormal liquor volume. Int $\mathbf{J}$ Reprod Contracept Obstet Gynecol 2014;3:181-4. 